\title{
Prevalence of excessive screen time and correlates factors in Brazilian schoolchildren
}

\section{Prevalência de tempo de tela excessivo e fatores correlatos em escolares brasileiros}

\section{AUTHOR'S \\ Dartagnan Pinto Guedes ${ }^{1}$ (D) \\ Robson Antônio Desiderá1 (i) \\ Hélcio Rossi Gonçalves ${ }^{\text {(D) }}$ \\ 1 University of Northern Parana, Londrina, Parana, Brazil. \\ 2 State University of Londrina, Parana, Brazil.}

\section{CORRESPONDING}

Dartagnan Pinto Guedes

darta@sercomtel.com.br

Rua Ildefonso Werner 177, Condomínio

Royal Golf, Londrina, Paraná, Brazil.

CEP: 86055-545.

DOI

$10.12820 /$ rbafs.23e0003
Copyright: This is an open-access article distributed under the terms of the Creative Commons Attribution License ${ }^{\circledR}$, which permits unrestricted use, distribution, and reproduction in any medium, provided that the original author and source are credited.

\begin{abstract}
The objective of this study was to identify excessive screen time, through the use of TV and other screen-based devices, including computers, videogames, tablets and smartphones, and analyze associated demographic, behavioral and anthropometric correlates. This is a cross-sectional school-based epidemiological study of approximately 17,000 schoolchildren aged 4-20 years who participated in the 2014 Healthy Paraná Project. Anthropometric measurements were collected by applying a questionnaire with structured questions. Excessive screen time was defined as the combined use of TV and other screen-based devices for $>2$ hours/day. Data were analyzed using bivariate analysis and hierarchical multiple regression. The overall prevalence of excessive screen time was $70.4 \%$ [68.1-72.9]. Multivariate analysis showed a significant association between excessive screen time and age $(\mathrm{OR}=1.92 ; 95 \% \mathrm{CI}: 1.60-2.33)$, economic status $(\mathrm{OR}=2.48$; 95\%CI: 1.99-3.17), mother's schooling $(\mathrm{OR}=1.98$; 95\%CI: 1.57-2.68), living area $(\mathrm{OR}=1.26$; 95\%CI: $1.04-1.56)$ and urbanization $(\mathrm{OR}=2.94 ; 95 \% \mathrm{CI}: 2.41-3.75)$. Among the behavioral correlates, less physical activity (OR $=1.42 ; 95 \% \mathrm{CI}: 1.25-1.85)$, low fruit/vegetable intake $(\mathrm{OR}=2.89 ; 95 \% \mathrm{CI}: 2.25-3.70)$, consuming sweetened products/soft drinks $(\mathrm{OR}=2.07 ; 95 \% \mathrm{CI}$ : 1.63-2.70) and fewer hours of sleep $(\mathrm{OR}=$ 2.01; 95\%CI: 1.60-2.62) were independently associated with excessive screen time. Likewise, excess body weight $(\mathrm{OR}=1.81 ; 95 \% \mathrm{CI}: 1.35-2.51)$ and abdominal fat $(\mathrm{OR}=2.01 ; 95 \% \mathrm{CI}: 1.62-2.73)$ were significantly associated with the outcome. In conclusion, the findings of the study suggest that policies and interventions targeting health education programs in school and family settings should include elements that focus on reducing excessive screen time.
\end{abstract}

Keywords: Child; Adolescent; School health; Lifestyle; Sedentary behavior.

RESUMO

O objetivo do estudo foi identificar a exposição ao tempo de tela excessivo, mediante o uso de TV e de outros dispositivos de tela, incluindo computador, videogame, tablet e smartphone, e analisar correlatos demográficos, comportamentais e antropométricos associados. Trata-se de estudo epidemiológico transversal de base escolar, com aproximadamente 17 mil escolares de 4 a 20 anos que participaram do Projeto Paraná Saudável em 2014. Foram realizadas medidas antropométricas e aplicado questionário com questôes estruturadas para levantar as informaçôes. Tempo de tela excessivo foi definido pelo uso combinado de TV e outros dispositivos de tela por tempo $>2$ horas/dia. Os dados foram tratados estatisticamente mediante análise bivariada e regressão múltipla hierarquizada. Prevalência global de tempo de tela excessivo foi de 70,4\% (IC95\%: 68,1-72,9). Análise multivariada apontou associação significativa entre tempo de tela excessivo e idade $(O R=1,92 ; I C 95 \%: 1,60-2,33)$, classe econômica $(O R=2,48 ;$ IC95\%: 1,99-3,17), escolaridade materna $(O R=1,98 ; 95 \% C I: 1,57-2,68)$, área de moradia $(O R=1.26 ;$ IC95\%: 1.04-1.56) e urbanização $(O R=$ 2,94; IC95\%: 2,41-3,75). Entre fatores comportamentais, menor prática de atividade física $(O R=1,42$; IC95\%: 1,25-1,85), baixo consumo de frutas/hortaliças (OR =2,89; IC95\%:2,25-3,70), elevado consumo de produtos açucarados/refrigerantes $(O R=2,07$; IC95\%: 1,63-2,70) e menos horas de sono $(O R=2,01$; IC95\%: 1,60-2,62) se mostraram independentemente associados ao tempo de tela excessivo. Da mesma forma, excesso de peso corporal $(O R=1,81 ;$ IC95\%: 1,35-2,51) e gordura abdominal $(O R=2,01 ;$ IC95\%: 1,62-2,73) apresentaram associaçôes significativas com o desfecho. Concluindo, achados do estudo sugerem que politicas e intervençôes destinadas aos programas de educação em saúde nos contextos escolar e familiar devam incluir componentes que se concentram na redução do tempo de tela excessivo.

Palavras-chave: Criança; Adolescente; Saúde escolar; Estilo de vida; Comportamento sedentário.

\section{Introduction}

Sedentary behavior refers to remaining in a sitting or reclining position in a state of wakefulness spending a minimum of energy $(\leq 1.5$ units of equivalent ener- gy [Mets] $)^{1}$. The most common sedentary behavior is screen time, that is, time spent watching television, playing videogames and using a computer, tablet or smartphone. Compared to other sedentary behaviors, 
such as sitting in a classroom, reading, listening to music, talking with friends, etc., screen time tends to exhibit greater variation among young people and more effective voluntary control ${ }^{2}$.

Recent studies have shown that, regardless of physical activity level, greater screen time at young ages is closely related to a number of harmful effects on health, including overweight and obesity, changes in cardiometabolic markers, metabolic syndrome and lower mineral content, with important lifelong repercussions $^{3}$. Moreover, excessive screen time favors the adoption of a poor $\operatorname{diet}^{4}$, psychosocial problems ${ }^{5}$, sleep disorders ${ }^{6}$ and diminished school performance ${ }^{2}$.

Due to the increased risk in various dimensions of physical and mental health, the guidelines proposed by public health entities worldwide recommend that school-age children and adolescents accumulate no more than 2 hours/day of screen time ${ }^{7}$. However, epidemiological surveys conducted in different countries have shown that only a small proportion of these individuals comply with screen time guidelines s,4,8-10 $^{2}$ and that average screen time can reach 6 hours $/ \mathrm{day}^{8}$. In Brazil, a systematic review investigated 24 surveys carried out in young people, revealing a prevalence of excess TV viewing, varying between $11.3 \%$ and $79.5 \%{ }^{11}$. Furthermore, National School Health Research (PeNSE) data collected from $9^{\text {th }}$ grade students in public and private schools in all the state capitals and the Federal District found that $61.3 \%$ of girls and $58.1 \%$ of boys watch television for more than 2 hours a day ${ }^{12}$. It is also important to note that the trend towards excessive screen time in adolescents persists in adulthood ${ }^{3}$.

Given these findings, it is essential to attempt to minimize the time young people spend in front of screens. An earlier systematic review collected data on interventions performed in children and adolescents, but with slightly favorable results ${ }^{13}$. In this respect, identifying the correlates associated with screen time may more effectively guide future interventions aimed at increasing the chances of success. Studies involving young Brazilians have sought to identify screen time correlates ${ }^{14,15}$. However, they exhibited important limitations, such as small sample sizes, restricted geographic areas, little sociocultural diversity, and narrow age range, in addition to considering only TV viewing time, disregarding all other screen display devices

As such, the aim of the present study was to identify excessive screen time, including TV viewing and other screen-based devices (computers, videogames, tablets and smartphones), in a representative sample of school-age children and adolescents in Paraná state, Brazil, and establish associations with demographic, behavioral and anthropometric correlates.

\section{Methods}

The data analyzed are from the Healthy Paraná Project, a cross-sectional school-based study aimed at analyzing the associations between anthropometric nutritional status, lifestyle behaviors as well as school and family setting indicators in young people aged 4 to 20 years enrolled in the public schools of Paraná state, Brazil.

In 2014, the public school population in Paraná was around 1.8 million students. The sample size was established assuming an unknown success rate ( $\mathrm{p}=50 \%)$, 95\% confidence interval and 3\% sampling error. However, considering that sample planning involved a cluster, the design effect was defined as three and sample size was increased by $25 \%$ in order to compensate for possible losses, resulting in 17,438 students in the initial sample. However, the final sample was composed of 17,074 students (8,776 girls and 8,298 boys).

Sample composition was determined by a random draw involving a cluster of four stages: geographic microregions, cities, schools, and grades, with probability proportional to size. The students selected for the sample and their respective parents or guardians were informed about the nature and objectives of the study, in addition to ensuring their anonymity, the non-influence of school performance, and inviting them to take part in data collection. Those who refused to participate in the study or did not respond to the invitation after being contacted three times on different days and at different times were considered sampling losses. The rights of all participants were guaranteed in the informed consent form signed by the students or their legal guardians.

The intervention protocols used were approved by the Research Ethics Committee of the Universidade Norte do Paraná - Plataforma Brasil (no. 95.056/2012). The study originally proposed to collect anthropometric data and apply a 50-item questionnaire divided into five sections: demographic aspects, eating habits, sleep, physical activity, and sedentary behavior.

The questionnaire was applied individually to each student, at a single session held at the school during class time. However, for kindergarten and $1^{\text {st }}$ to $5^{\text {th }}$ graders (age $\leq 11$ years), the questionnaire was applied in the form of a face-to-face interview in the presence of their parents/guardians, who, when asked, helped the stu- 
dents answer the questions. In the other grades (grades 6 to 9 of elementary school and 9 to 11 of high school), students were handed out the questionnaire with instructions and recommendations for filling it out, and no time limit was established for completing the instrument. The average time spent on the questionnaire was 40 minutes. Questionnaire reliability was analyzed by reapplying it to $10 \%$ of the subjects seven days later. All the items demonstrated Cohen's kappa $\geq 0.70$.

Data were collected between August/2013 and June/2014 by a team of 40 investigators, divided into eight groups distributed into the different geographic regions and cities. Anthropometric data consisted of height, body weight and waist circumference measures, in line with the methodology proposed by the World Health Organization ${ }^{16}$. Body mass index (BMI) was calculated as the ratio between weight in kilograms and height in meters $\left(\mathrm{kg} / \mathrm{m}^{2}\right)$ and waist height ratio (WHR) as the waist circumference divided by height, expressed in centimeters. Based on BMI, the anthropometric nutritional status of the students was classified into four categories, according to the cutoff points for sex and aged suggested by the International Obesity Task Force - IOFT ${ }^{17}$ : low body weight, eutrophic, overweight and obesity. WHR values were used to analyze abdominal fat accumulation, adopting a cutoff point of $0.50^{18}$.

With respect to demographic aspects, in addition to sex and age, information was collected on ethnicity, economic class, mother's schooling, family structure, living area and hometown population. Economic class was established based on National Association of Market Research Companies (ABEP) guidelines ${ }^{19}$. Eating habit information was obtained using the Youth Risk Behavior Survey (YRBS), translated, adapted and validated for Brazil ${ }^{20}$. In this case, the students reported the intake frequency of fruits/vegetables and sweetened products/soft drinks in the week prior to data collection. Intake frequency was classified as none; 1-4 days/week; $\geq 5$ days/week.

Sleep duration indicators were collected considering weekdays and weekends, based on a typical or usual week and four questions: on school days, (a) what time do you usually go to bed? and (b) what time do you wake up? On weekends, (a) what time do you usually go to bed? and (b) what time do you wake up? With this information, sleep duration was calculated for weekdays and weekends. The weighted mean of weekday and weekend data was used to obtain sleep duration per night.
The Physical Activity Questionnaire for Older Children - PAQ-C and Physical Activity Questionnaire for Adolescents - PAQ-A, translated and validated for Brazil, were used to determine physical activity levels ${ }^{21}$. Specific cutoff points for sex and age, based on tertile distribution, were used to characterize the scores. Thus, the least active group of students was stratified with PAQ-C or PAQ-A scores $\leq 1^{\text {st }}$ tertile, the moderately active group with scores between the $1^{\text {st }}$ and $2^{\text {nd }}$ tertile, and the most active group with scores $\geq 2^{\text {nd }}$ tertile.

Screen time was determined by structured questions on TV viewing and using a computer, videogame, tablet and smartphone during a typical or usual week. Answers were divided into four categories ranging from "none" to "> 4 hours/day". The questions considered TV viewing time separately from computer, videogame, tablet and smartphone screen time, on weekdays and weekends. The weighted mean of weekday and weekend data was used to calculate students' screen time per day. Excessive screen time was defined as the combined use of TV and other screen devices for $>2$ hours/day ${ }^{7}$.

The data were digitized in duplicate in the EpiData 3.1 program and analyses were conducted using Statistical Package for the Social Sciences (SPSS) 22.0 software. Screen time estimates and demographic, behavioral and anthropometric correlates were presented in percentages, along with their $95 \%$ confidence intervals (95\% CI). To analyze the associations between excessive screen time and potential correlates, the prevalence ratio was calculated. Statistical differences between the strata under study were determined using the chi-squared test $\left(\chi^{2}\right)$. Next, correlates that show at least marginally significant associations ( $\mathrm{p} \leq 0.20)$ in bivariate analysis were included in hierarchized multiple regression procedures. In this case, the correlates were included in blocks, and demographic aspects (level one) were the first to enter the model, followed by those related to behavioral components (level two) and finally, anthropometric indicators (level three). All the correlates with statistical significance $(\mathrm{p}<0.05)$ remained in the multivariate model.

\section{Results}

Descriptive information of the study sample is shown in table 1. Approximately half the sample consists of girls (51.4\%) and the highest concentration of schoolchildren is found in 8-to-15-year-olds $(\approx 73 \%)$. Demographic aspects were comparable in both sexes; however, differences were identified in behavioral components and anthropometric indicators. 
Table 1 - Descriptive information of the sample selected for the Healthy Paraná Project, 2014.

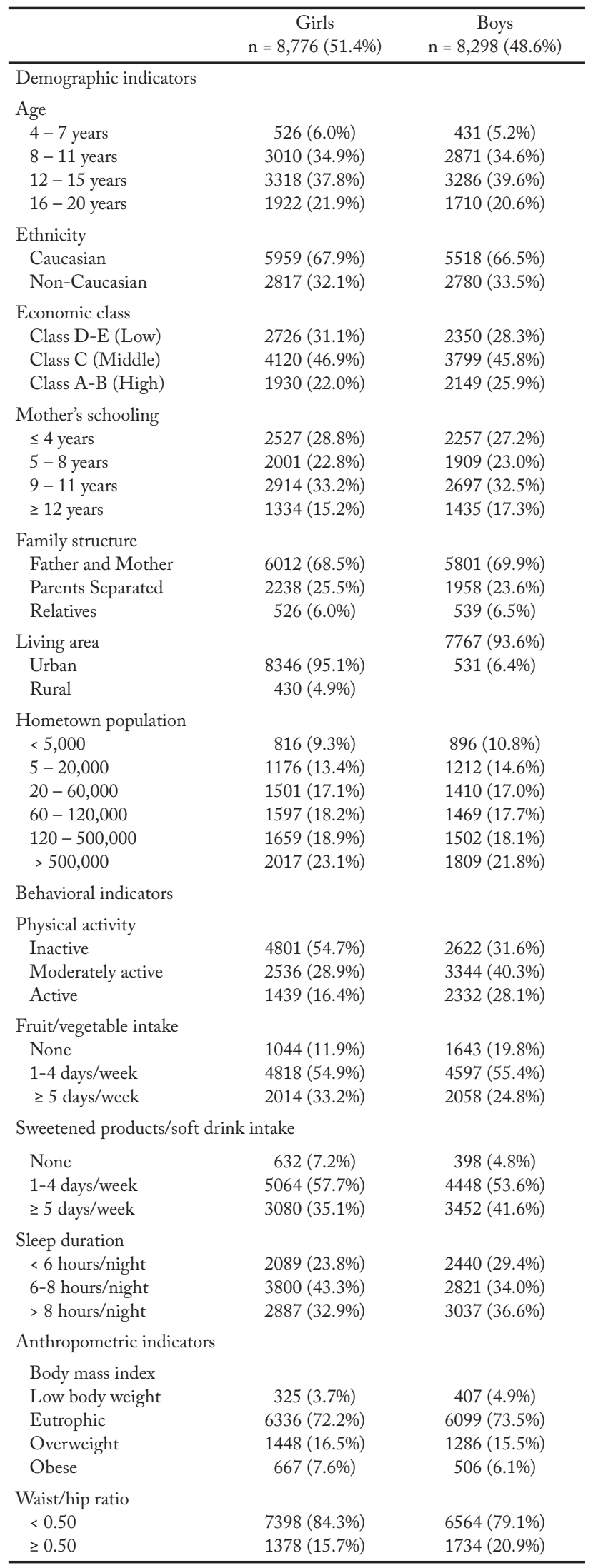

Table 2 shows TV viewing times, according to sex and age, separately from computers, videogames, tablets and smartphones. Considering the different age groups, similar percentages of girls and boys reported watching TV (37.1\%; CI95\%: 35.2-39.1) and 39.3\% (CI95\%: 37.2-41.2), respectively and using a computer, videogame, tablet or smartphone (49.1\%; CI95\%: 46.0-52.3 and 44.2; CI95\%: 41.5-47.0, respectively) for $\leq 2$ hours/ day. However, a significantly higher proportion of girls watch TV (28.7\%; CI95\%: 27.1-30.4) versus 23.9\% (CI95\%: 22.5-25.3; $\mathrm{p}=0.033$ ), while more boys use computers, videogames, tablets or smartphones (26.9\%; CI95\%: 25.4-28.5) versus 20.8\% (CI95\%: 19.5-22.1; $\mathrm{p}=0.020)$ for $>4$ hours/day. Up to 15 years of age in both sexes, more students spend $>2$ hours/day watching TV than use other screen-based devices. However, time spent by older students on computers, videogames, tablets or smartphones was the main contributor to excessive screen time, especially among boys.

Estimated prevalence of excessive screen time, calculated by stratifying each demographic, behavioral and anthropometric correlate, is presented in table 3. The overall prevalence of excessive screen time was 70.4\% (CI95\%: 68.1-72.9). Of the potential correlates considered, bivariate analyses show that sex and ethnicity were not statistically significant $(\mathrm{p}<0.20)$.

Hierarchized multiple regression results are described in table 4 . With respect to demographic correlates, the final model revealed significant associations between excessive screen time and age, economic class, mother's schooling, living area and number of hometown inhabitants. Among the behavioral components, the four correlates considered (physical activity, fruit/ vegetable intake, consuming sweetened products/soft drink and sleep duration) were associated with screen time of $>2$ hours/day. Likewise, the anthropometric correlates related to indicators of nutritional status (BMI) and body fat accumulation (WHR) were significantly associated with the outcome.

\section{Discussion}

The aim of the study was to collect updated information on excessive screen time in young students in Paraná state, Brazil, and their demographic, behavioral and anthropometric correlates. The primary findings demonstrated that around three out of every ten students reported spending $\leq 2$ hours/day watching TV and using a computer, videogame, tablet or smartphone, complying with current screen time guidelines recom- 
Table 2 - Screen time exposure according to sex and age of the schoolchildren from Paraná state, Brazil, 2014.

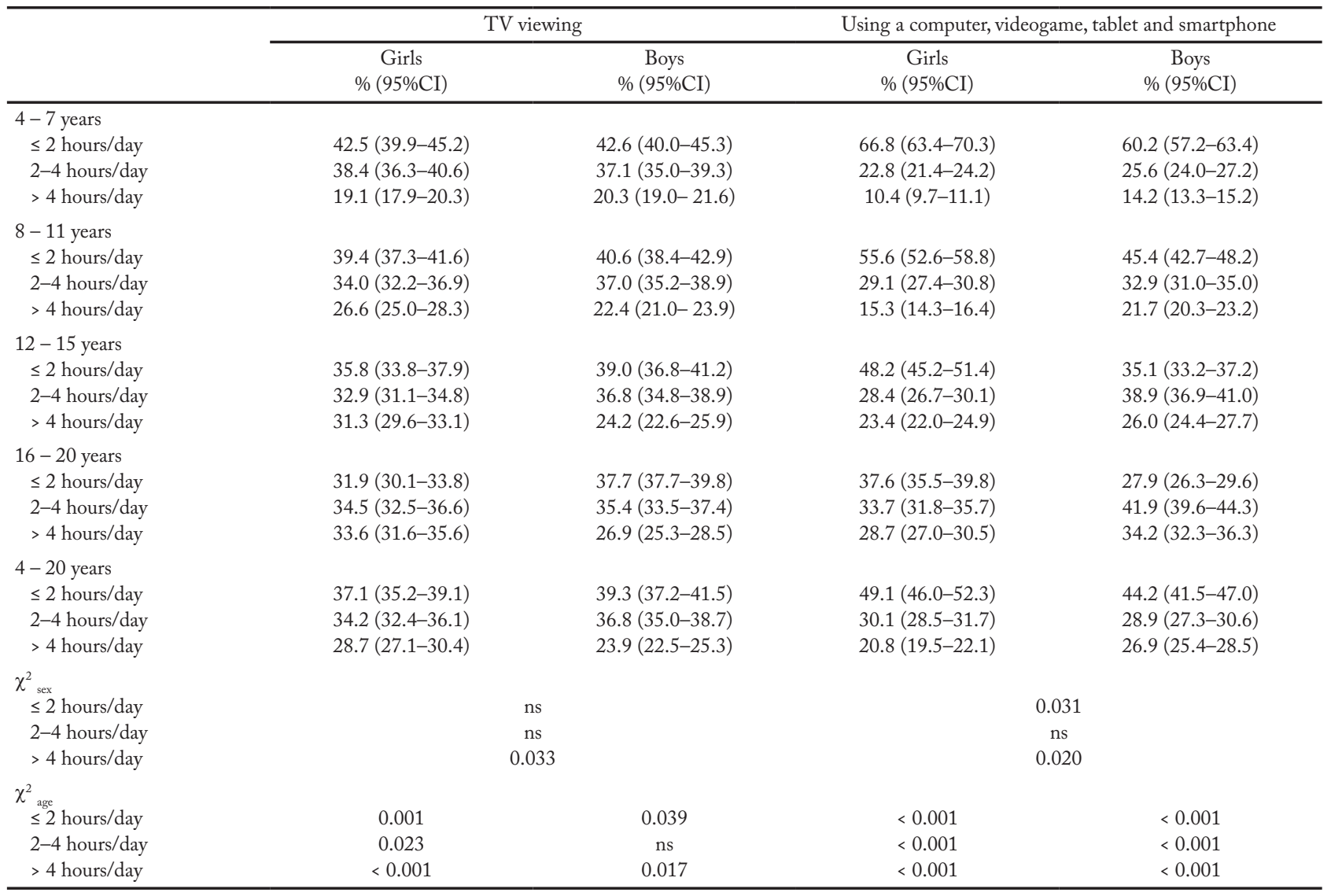

ns $=$ no significant .

mended by public health institutions ${ }^{7}$. In addition to being older, belonging to a higher economic class, their mother having more schooling and living in cities with larger populations, the students who reported excessive screen time were the least physically active, consumed less healthy food, slept for fewer hours, had higher body weight and greater abdominal fat accumulation.

Comparisons between the findings of the present study and those of earlier surveys in Brazil and other countries are difficult to make due to the different methodological designs used, non-representative samples of the population under study, as well as different measurement procedures, cutoff points and screenbased devices. Investigations with wider student age ranges (from 4 to 20 years) are scarce and data clusters by age are not consensual.

However, if on one hand the proportion of students that comply with the current screen time guidelines contained in the Healthy Paraná Project is low $(\approx 30 \%)$, on the other, it does not to seem different from that observed in other studies. For example, considering specifically excessive TV viewing time, school-based population surveys conducted in Brazilian adolescents between 14 and 20 years old revealed a prevalence of $59.1 \%$ and $27.3 \%$ in the states of Pernambuco ${ }^{14}$ and Santa Catarina ${ }^{15}$, respectively. National School Health Survey (PeNSE) data collected from $9^{\text {th }}$ graders at public and private schools in Brazilian capitals and the Federal District showed that $40.1 \%$ of the students watched TV $\leq 2$ hours/day ${ }^{12}$. The Health Behaviour in School-Age Children report, an international study of around 200,000 adolescents aged 11,13 and 15 years of age from 41 countries in Europe and North America, found that between $37 \%$ and $50 \%$ of these individuals watched TV $\leq 2$ hours/day ${ }^{9}$ in the United States. More recent data from the Youth Risk Behavior Survey, a biennial survey of $9^{\text {th }}$ to $12^{\text {th }}$ graders, shows that $41.7 \%$ of American adolescents use a computer, videogame, tablet or smartphone $\geq 3$ hours/day, and $24.7 \%$ watch TV for the same amount of time ${ }^{22}$.

In addition to the methodological differences identified in the studies, questions related to the sociocultural and environmental context inherent to each Brazilian region and other countries may influence 
Table 3 - Prevalence $(95 \% \mathrm{CI})$ and prevalence ratio $(95 \% \mathrm{CI})$ of excessive screen time with stratification for demographic, behavioral and anthropometric correlates of the schoolchildren from Paraná state, Brazil, 2014.

\begin{tabular}{|c|c|c|c|}
\hline & Prevalence & Prevalence Ratio & $\mathrm{p}$-value \\
\hline Global & $70.4(68.1-72.9)$ & & \\
\hline \multicolumn{4}{|c|}{ Demographic indicators } \\
\hline \multicolumn{4}{|l|}{ Sex } \\
\hline Girls & $68.7(65.8-71.7)$ & 1 & \multirow[t]{2}{*}{0.364} \\
\hline Boys & $72.1(69.0-75.3)$ & $1.03(0.95-1.11)$ & \\
\hline \multicolumn{4}{|l|}{ Age } \\
\hline $4-7$ years & $61.2(58.1-64.5)$ & 1 & \multirow{4}{*}{0.012} \\
\hline $8-11$ years & $69.8(66.0-73.7)$ & $1.12(0.98-1.31)$ & \\
\hline $12-15$ years & $74.7(70.5-79.0)$ & $1.18(1.03-1.42)$ & \\
\hline $16-20$ years & $80.4(75.6-85.5)$ & $1.25(1.07-1.56)$ & \\
\hline \multicolumn{4}{|l|}{ Ethnicity } \\
\hline Caucasian & $72.8(68.8-76.9)$ & $1.06(0.97-1.17)$ & \multirow[t]{2}{*}{0.288} \\
\hline Non-Caucasian & $68.0(64.4-71.7)$ & 1 & \\
\hline \multicolumn{4}{|l|}{ Economic class } \\
\hline Class D-E (Low) & $58.2(55.3-61.2)$ & 1 & \multirow{3}{*}{$<0.001$} \\
\hline Class C (Middle) & $68.7(65.0-72.5)$ & $1.15(1.01-1.36)$ & \\
\hline Class A-B (High) & $84.5(78.4-89.6)$ & $1.38(1.15-1.77)$ & \\
\hline \multicolumn{4}{|l|}{ Mother's schooling } \\
\hline$\leq 4$ years & $61.9(58.8-65.1)$ & 1 & \multirow{4}{*}{0.048} \\
\hline $5-8$ years & $66.8(63.4-70.3)$ & $1.06(0.96-1.22)$ & \\
\hline $9-11$ years & $72.0(68.1-76.0)$ & $1.14(1.00-2.35)$ & \\
\hline$\geq 12$ years & $81.3(76.4-86.3)$ & $1.27(1.08-1.56)$ & \\
\hline \multicolumn{4}{|l|}{ Family structure } \\
\hline Mother and Father & $65.7(62.2-69.2)$ & 1 & \multirow{3}{*}{0.164} \\
\hline Parents Separated & $75.5(71.2-79.9)$ & $1.13(0.98-1.36)$ & \\
\hline Relatives & $70.1(66.3-74.0)$ & $1.06(0.92-1.27)$ & \\
\hline \multicolumn{4}{|l|}{ Living area } \\
\hline Urban & $81.8(77.2-86.4)$ & $1.35(1.13-1.73)$ & \multirow[t]{2}{*}{0.002} \\
\hline Rural & $59.0(55.7-62.4)$ & Reference & \\
\hline \multicolumn{4}{|l|}{ Hometown population } \\
\hline$<5,000$ & $57.5(54.6-60.5)$ & Reference & \\
\hline $5-20,000$ & $63.9(60.6-67.3)$ & $1.09(0.97-1.29)$ & \\
\hline $20-60,000$ & $68.4(64.7-72.1)$ & $1.16(1.02-1.40)$ & $<0.001$ \\
\hline $60-120,000$ & $71.8(67.8-75.9)$ & $1.21(1.06-1.50)$ & \\
\hline $120-500,000$ & $77.9(73.5-82.4)$ & $1.30(1.10-1.67)$ & \\
\hline$>500,000$ & $83.4(78.3-88.6)$ & $1.41(1.16-1.80)$ & \\
\hline Behavioral indicators & & & \\
\hline Physical activity & & & \\
\hline Inactive & $82.8(77.8-87.9)$ & $1.36(1.14-1.74)$ & 0001 \\
\hline Moderately active & $69.1(65.3-73.0)$ & $1.15(0.98-1.41)$ & 0.001 \\
\hline Active & $59.6(56.7-62.6)$ & 1 & \\
\hline Fruit/vegetable intake & & & \\
\hline None & $84.6(79.3-90.0)$ & $1.47(1.22-1.89)$ & O $\cap \Omega 1$ \\
\hline 1-4 days/week & $71.2(67.4-75.3)$ & $1.25(1.06-1.58)$ & $<0.001$ \\
\hline$\geq 5$ days/week & $55.5(52.8-58.2)$ & 1 & \\
\hline Sweetened products/s & drink intake & & \\
\hline None & $58.1(55.2-61.1)$ & 1 & \\
\hline 1-4 days/week & $71.6(67.8-75.8)$ & $1.20(1.03-1.48)$ & 0.003 \\
\hline$\geq 5$ days/week & $80.5(75.7-85.4)$ & $1.35(1.14-1.77)$ & \\
\hline Sleep duration & & & \\
\hline$<6$ hours/night & $87.3(81.8-92.8)$ & $1.58(1.33-2.10)$ & ـ 001 \\
\hline 6-8 hours/night & $70.9(67.1-74.8)$ & $1.29(1.07-1.73)$ & \\
\hline$>8$ hours/night & $53.2(50.6-56.0)$ & 1 & \\
\hline Anthropometric indic & & & \\
\hline Body mass index & & & \\
\hline Low body weight & $61.3(58.2-64.5)$ & $1.01(0.89-1.21)$ & \\
\hline Eutrophic & $60.8(57.8-63.9)$ & 1 & 0.022 \\
\hline Overweight & $77.1(72.5-81.8)$ & $1.24(1.05-1.69)$ & \\
\hline Obese & $82.4(77.4-87.6)$ & $1.33(1.11-1.76)$ & \\
\hline Waist/hip ratio & & & $0 \Omega 03$ \\
\hline$<0.50$ & $59.2(56.3-62.2)$ & 1 & 0.003 \\
\hline$\geq 0.50$ & $81.7(76.8-86.8)$ & $1.34(1.12-1.79)$ & \\
\hline
\end{tabular}

Table 4 - Hierarchized multiple logistic regression for demographic (level 1), behavioral (level 2) and anthropometric (level 3) correlated of excessive screen time of schoolchildren from Paraná state, Brazil, 2014.

\begin{tabular}{|c|c|c|}
\hline Correlates & $\mathrm{OR}_{\text {Crude }}(95 \% \mathrm{CI})^{\mathrm{a}}$ & $\mathrm{OR}_{\text {Adjusted }}(95 \%)^{\mathrm{b}}$ \\
\hline \multicolumn{3}{|l|}{ Level 1} \\
\hline $\begin{array}{l}\text { Age } \\
\qquad \begin{array}{l}4-7 \text { years } \\
8-11 \text { years } \\
12-15 \text { years } \\
16-20 \text { years }\end{array}\end{array}$ & $\begin{array}{c}1 \\
1.31(1.07-1.61) \\
1.52(1.22-1.93) \\
1.98(1.57-2.60)\end{array}$ & $\begin{array}{c}1 \\
1.27(1.08-1.51) \\
1.46(1.20-1.82) \\
1.92(1.60-2.33)\end{array}$ \\
\hline $\begin{array}{l}\text { Economic Class } \\
\text { Class D-E (Low) } \\
\text { Class C (Middle) } \\
\text { Class B-A (High) }\end{array}$ & $\begin{array}{c}1 \\
1.74(1.37-2.24) \\
2.53(1.92-3.37)\end{array}$ & $\begin{array}{c}1 \\
1.67(1.38-2.08) \\
2.48(1.99-3.17)\end{array}$ \\
\hline $\begin{array}{l}\text { Mother's Schooling } \\
\leq 4 \text { years } \\
5-8 \text { years } \\
9-11 \text { years } \\
\geq 12 \text { years }\end{array}$ & $\begin{array}{c}1 \\
1.22(1.02-1.52) \\
1.61(1.26-2.13) \\
2.05(1.55-2.87)\end{array}$ & $\begin{array}{c}1 \\
1.18(0.98-1.43) \\
1.57(1.31-2.01) \\
1.98(1.57-2.68)\end{array}$ \\
\hline $\begin{array}{l}\text { Living area } \\
\text { Urban } \\
\text { Rural }\end{array}$ & $\begin{array}{c}1 \\
1.34(1.10-1.68)\end{array}$ & $\begin{array}{c}1 \\
1.26(1.04-1.56)\end{array}$ \\
\hline $\begin{array}{l}\text { Hometown Population } \\
\quad<5,000 \\
5-20,000 \\
20-60,000 \\
60-120,000 \\
120-500,000 \\
>500,000\end{array}$ & $\begin{array}{c}1 \\
1.23(1.01-1.51) \\
1.47(1.17-1.98) \\
1.82(1.41-2.47) \\
2.11(1.59-2.96) \\
2.96(2.25-3.99)\end{array}$ & $\begin{array}{c}1 \\
1.19(0.98-1.42) \\
1.46(1.22-1.85) \\
1.80(1.50-2.31) \\
2.06(1.65-2.77) \\
2.94(2.41-3.75)\end{array}$ \\
\hline Level 2 & & \\
\hline $\begin{array}{l}\text { Physical activity } \\
\text { Inactive } \\
\text { Moderately active } \\
\text { Active }\end{array}$ & $\begin{array}{c}2.13(1.62-2.95) \\
1.51(1.29-2.03) \\
1\end{array}$ & $\begin{array}{c}1.96(1.56-2.67) \\
1.42(1.25-1.85) \\
1\end{array}$ \\
\hline $\begin{array}{l}\text { Fruit/vegetable intake } \\
\text { None } \\
1-4 \text { days/week } \\
\geq 5 \text { days/week }\end{array}$ & $\begin{array}{c}3.05(2.30-4.11) \\
1.70(1.33-2.25) \\
1\end{array}$ & $\begin{array}{c}2.89(2.25-3.70) \\
1.56(1.26-2.02) \\
1\end{array}$ \\
\hline $\begin{array}{l}\text { Sweetened products/sc } \\
\text { drink intake } \\
\text { None } \\
\text { 1-4 days/week } \\
\geq 5 \text { days/week }\end{array}$ & $\begin{array}{c}1 \\
1.62(1.28-2.12) \\
2.23(1.67-3.11)\end{array}$ & $\begin{array}{c}1 \\
1.42(1.17-1.83) \\
2.07(1.63-2.70)\end{array}$ \\
\hline $\begin{array}{l}\text { Sleep duration } \\
<6 \text { hours/night } \\
6-8 \text { hours/night } \\
>8 \text { hours/night }\end{array}$ & $\begin{array}{c}2.18(1.65-3.03) \\
1.44(1.18-1.85) \\
1\end{array}$ & $\begin{array}{c}2.01(1.60-2.62) \\
1.26(1.07-1.60) \\
1\end{array}$ \\
\hline Level 3 & & \\
\hline $\begin{array}{l}\text { Body mass index } \\
\text { Low body weight } \\
\text { Eutrophic } \\
\text { Overweight } \\
\text { Obese }\end{array}$ & $\begin{array}{c}1.09(0.98-1.29) \\
1 \\
1.88(1.45-2.51) \\
2.07(1.52-2.97)\end{array}$ & $\begin{array}{c}1.01(0.92-1.19) \\
1 \\
1.69(1.33-2.28) \\
1.81(1.35-2.51)\end{array}$ \\
\hline $\begin{array}{l}\text { Waist/hip ratio } \\
\quad<0.50 \\
\geq 0.50\end{array}$ & $2.23(1.69-3.11)$ & $\begin{array}{c}1 \\
2.01(1.62-2.73)\end{array}$ \\
\hline
\end{tabular}

a Non-adjusted Odds ratio b Odds ratio adjusted for the remaining variables included in the model 
excessive screen time, thereby justifying the differences between studies. Easy access to electronic devices, changes in family relationships, fewer public spaces for outdoor activities and lack of security in urban centers result in young people's engaging in more leisure activities at home, which leads to more exposure to screenbased devices ${ }^{4}$. Furthermore, the simultaneous use of more than one electronic device is increasingly common in young people, which favors a rise in screen time in this population ${ }^{2}$.

Several correlates identified in the present study are consistent with literature reports ${ }^{2,4,9,10,15,23}$. However, it is important to underscore that, in contrast to some studies $^{15,23}$ but in line with others ${ }^{2,4,9,10}$, sex showed no significant association with excessive screen time. This lack of consensus may be related to the number of electronic devices considered in the definition of screen time in the different studies. Research that has shown sex as a correlate of screen time only investigated TV viewing time, while other studies also considered the use of a computer, videogame, tablet and smartphone. The family's education should also be taken into account. In some families, girls are more encouraged than in others to stay at home for longer periods studying and doing domestic chores, increasing the likelihood of watching TV and using other screen-based devices.

Age was found to be an important correlate of excessive screen time, which coincides with the findings of earlier studies ${ }^{2,49,10,15,23}$. Older students exhibit progressively more probability of exceeding the recommended daily screen time than their younger counterparts, such that, at 16-20 years of age, the chance of students spending $>2$ hours/day using screen-based devices is about two-fold higher than those aged 4-7 years (OR = 1.92; CI95\%: 1.60-2.33). Another aspect observed in the study is the trend to less TV time with advancing age, concomitantly with a rise in computer, videogame, tablet and smartphone use. This situation may be related to the fact that older adolescents are not as restricted by their parents to use electronic devices, show less interest and expectation for other types of entertainment involving physical activity, especially sports, feel strongly attracted to social networks, intensify their online interactions with peers, and may use the computer more effectively for study and work ${ }^{3}$.

No significant associations were observed between excessive screen time, ethnicity and family structure. Bivariate analysis demonstrated that family structure was a likely correlate of excessive screen time $(\mathrm{p}=$
0.164); however, following multivariate analysis, after adjusting for the other demographic variables, it was no longer associated. In relation to economic class, in developed countries economic level has been shown to be negatively associated with screen time, and young people from less privileged families spend more time using screen-based devices, especially when considering only time spent watching $\mathrm{TV}^{9}$. However, in the present study and similar to that reported in other Brazilian surveys ${ }^{14,15}$ and in Latin American countries ${ }^{10,23}$, the opposite trend was observed, that is, students from families with higher purchasing power are more prone to using screen-based devices for $>2$ hours/day. As such, the higher purchasing power of Brazilian families and resulting ease in acquiring technological equipment for their children have contributed strongly to raising the screen time of students, unlike that observed in more developed countries.

With respect to living area, the urban/rural gradient was also a correlate of excessive screen time, which is consistent with the findings of earlier studies involving young Brazilians ${ }^{15}$ and individuals from other Latin American countries ${ }^{10,23}$. Although this observation may partially reflect differences in the economic class of families living in urban and rural areas, it is important to note that the association between excessive screen time and living area remained in multivariate analyses, even after the other demographic indicators were adjusted, including economic class. This suggests that students from urban areas likely have more access to screen-based technologies, for example, more TV channels and faster internet, which increases the chance of spending more time on screen devices.

Data stratified by the number of inhabitants in the students' hometown showed that excessive screen time is not restricted to large urban centers (83.4\%; CI95\%: 78.3-88.6). In this case, more than half the students that live in smaller, less developed cities (57.5\%; CI95\%: 54.6-60.5) also reported using screen-based devices for more than 2 hours/day. Multivariate analysis, controlling the other demographic correlates, indicated that living in cities with more than 500,000 inhabitants nearly triples the chances of students' exceeding screen time (OR $=2.94$; CI95\%: 2.41-3.75). This may be explained by the greater risk of social disorders and conflicts, caused by the high concentration of people, contributing significantly to families living in more populated centers placing greater value on entertainment and leisure options for their children that 
involve screen-based devices ${ }^{24}$.

In regard to physical activity, an earlier meta-analysis involving children and adolescents revealed that their association with screen time, when significant, was of low magnitude ${ }^{25}$. Furthermore, intervention proposals aimed at increasing physical activity have not achieved the desired effect of reducing TV viewing time ${ }^{26}$. However, the results obtained here demonstrate that less physically active young people are twice as likely to exceed the screen time recommended by current guidelines compared to their more active counterparts $(\mathrm{OR}=1.96$; 95\%CI: $1.56-2.67)$. Possible differences in the strength of the association between physical activity and screen time may sometimes occur due to the different ages of the young people sampled in the studies, measurement instruments used and analysis procedures applied in data interpretation.

The significant association with the intake of fruits/ vegetables and sweetened products/soft drinks reinforces the position that eating habits are another important behavioral correlate of excessive screen time. In this case, an inverse association was found between greater fruit/vegetable intake and screen time $>2$ hours/ day and a direct association between higher sweetened products/soft drink consumption and excessive screen time. Other studies also indicate, specifically in children and adolescents, that excessive screen time is associated with less healthy eating habits ${ }^{4}$. Given that watching TV accounts for the largest proportion of screen time, one of the reasons that may justify the close association between excessive screen time and unhealthy eating habits is the fact that young people are more intensely exposed to advertisements for sweetened products/soft drink, making them more likely to consume both types of food ${ }^{27}$. Moreover, the prolonged use of computers, videogames, tablets and smartphones may cause alienation and abstraction, which lead to less awareness of the need for healthy eating or result in young people ignoring meal times and substituting them with readyto-eat processed foods ${ }^{28}$.

Another finding obtained in the present study was the significant inverse relationship between excessive screen time and sleep duration, which corroborates other literature results ${ }^{6}$. The effects of exposure to screenbased devices on the sleep of students have been intensely investigated in recent decades. At this age, sleep is considered particularly important for learning and memory, in addition to having implications for emotional regulation and behavior. More specifically, poor sleep quality and insufficient duration are related to stimuli processing deficiencies and the ability to concentrate, which, in turn, translates into compromised academic performance ${ }^{29}$. In this case, if the screenbased device is used at night, three primary mechanisms may justify insufficient sleep duration. The first is the reduced time available for sleeping, given the time spent in front of the screen-based device. The second is related to psychological and physiological excitation, due to the involvement and interaction with electronic media content that interferes in young people's ability to fall asleep and remain asleep. Furthermore, screen brightness affects the circadian rhythm, mediated by the physiological suppression of melatonin, the sleep-promoting hormone ${ }^{30}$.

The fact that longer screen times correlated with greater excess weight and body fat is consistent with earlier findings observed in cross-sectional ${ }^{9}$ and longitudinal $^{3}$ studies, confirming the hypothesis that excessive screen time is strongly associated with anthropometric nutritional status. Investigators in the area have sought to attribute the behavioral traits of young people who use screen-based devices for extended periods of time (for example, greater intake of unhealthy food and less physical activity) to the association between excessive screen time and excess weight and body fat ${ }^{4,9}$. However, it is important to underscore that, specifically in the present study, both anthropometric indicators related to nutritional status (BMI and WHR) remained significantly associated with excessive screen time even when adjusted for demographic and behavioral correlates (physical activity, fruit/vegetable and sweetened products/soft drink intake and sleep duration). In this respect, future studies on the issue should be conducted to elucidate the independent effect of excessive screen time on greater weight and body fat accumulation.

Among the limitations of the present study is that the investigation method used involved a self-reported questionnaire, which may cause memory bias or even emphasis on positive findings. However, these indicators are reported by parents, guardians or the students themselves, the usual procedure in these types of studies and the most viable method of conducting schoolbased or population surveys. Furthermore, the large sample makes it possible, to a certain extent, to minimize potential inaccuracies in the estimates calculated. In addition, the cross-sectional analysis of the data precludes inferring causality in the association between 
excessive screen time and the correlates investigated, because the outcome and the remaining variables were identified at the same time.

On the other hand, the main strengths are related to the concept, design and implementation of the Healthy Paraná Project. The project exhibits cultural diversity, covers a wide geographic area, and provides robust updated data on the health-related lifestyle of students from a state in Southern Brazil, which makes it possible to generalize its findings to a broader population. The team of investigators completed the training phase before data collection, which were tested periodically via replicate measurements to ensure the quality of the information collected. The refusal rate to take part in the study was minimal, thereby guaranteeing the reliability of results.

In conclusion, the students selected for the study spent an excessive amount of time watching TV and in front of other screen-based devices (computer, videogame, tablet and smartphone), especially older individuals, the economically advantaged, those whose mothers had more schooling and residents of cities with high populations. Most of the students (around 70\%) exceeded the screen time recommended by current guidelines $(\leq 2$ hours/day). The inverse significant associations between excessive screen time and behavioral correlates (physical activity, healthy eating habits and sleep duration), along with a direct association with anthropometric correlates (greater weight and body fat accumulation), suggest that policies and interventions aimed at health education programs in school and family settings should concentrate on reducing excessive screen time.

\section{Conflict of interest}

The authors declared no conflict of interest.

\section{Funding}

The study was funded by the Secretary of Sport of the State of $\mathrm{Pa}$ rana, Brazil. The primary author is supported by Brazilian National Board for Scientific and Technological Development - CNPq.

\section{Authors' contributions:}

Guedes DP, Gonçalves HR and Desiderá RA participated equally in article design, data collection and analysis, writing and critical review of the manuscript.

\section{Acknowledgments}

The authors extend special thanks to staff of the Secretary of Sport of the State of Parana, Brazil, for valuable help in conduc- ting this study.

\section{References}

1. Sedentary Behaviour Research Network. Letter to the Editor: standardized use of the terms "sedentary" and "sedentary behaviours”. Appl Physiol Nutr Metab. 2012;37:540-42.

2. Temmel CSD, Rhodes R. Correlates of Sedentary Behaviour in Children and Adolescents Aged 7-18: A Systematic Review. Health Fit J Can. 2013;6:119-99.

3. Biddle SJ, Pearson N, Ross GM, Braithwaite R. Tracking of sedentary behaviours of young people: a systematic review. Prev Med. 2010;51:345-51.

4. Cillero IH, Jago R. Systematic review of correlates of screenviewing among young children. Prev Med. 2010;51:3-10.

5. Herman KM, Hopman WM, Sabiston CM. Physical activity, screen time and self-rated health and mental health in Canadian adolescents. Prev Med. 2015;73C:112-6.

6. Hale L, Guan S. Screen time and sleep among school-aged children and adolescents: a systematic literature review. Sleep Med Rev. 2015;21:50-8.

7. American Academy of Pediatrics; Council on Communications and Media. Children, adolescents, obesity, and the media. Pedriatrics. 2011;128:201-8.

8. Mark AE, Boyce WF, Janssen I. Television viewing, computer use and total screen time in Canadian youth. Paediatr Child Health 2006; 11(9):595-9.

9. Inchley J, Currie C, Young T, Samda IO, Torsheim T, Augustson L et al. Growing up unequal: gender and socioeconomic differences in young people's health and well-being. Health Behaviour in School-Aged Children (HBSC) Study: International Report from the 2013/2014 Survey. Health Policy for Children and Adolescents. No. 7. Copenhagen, Denmark: WHO Regional Office for Europe. 2016. p.1-292.

10. Janssen I, Medina C, Pedroza A, Barquera S. Screen time in Mexican children: findings from the 2012 National Health and Nutrition Survey (ENSANUT 2012). Salud Publica Mex 2013;55:484-91.

11. Barbosa Filho VC, Campos W, Lopes AS. Epidemiology of physical inactivity, sedentary behaviors, and unhealthy eating habits among Brazilian adolescents: a systematic review. Cien Saude Colet. 2014;19:173-93.

12. IBGE - Instituto Brasileiro de Geografia e Estatística. Pesquisa Nacional de Saúde do Escolar. PeNSE/2015. Rio de Janeiro: Coordenação de População e Indicadores Sociais/ IBGE. 2016

13. van Sluijs EM, Kriemler S, McMinn AM. The effect of community and family interventions on young people's physical activity levels: a review of reviews and updated systematic review. Br J Sports Med. 2011;45:914-22.

14. Tenório M, Barros M, Tassitano R, Bezerra J, Tenório J, Hallal P. Atividade física e comportamento sedentário em adolescentes estudantes do ensino médio. Rev Bras Epidemiol. 2010; 13:105-17.

15. Silva KS, Nahas MV, Peres KG, Lopes AS. Fatores associados à atividade física, comportamento sedentário e participação na Educação Física em estudantes do Ensino Médio em Santa Catarina, Brasil. Cad Saude Publica. 2009;25(10):2187-200.

16. World Health Organization - WHO. Physical Status: The Use and Interpretation of Anthropometry. Report of a WHO Expert Committee. WHO - Technical Report Series, v. 854, p.1-452. 1995. 
17. Cole TJ, Lobstein T. Extended international (IOTF) body mass index cut-offs for thinness, overweight and obesity. Pediatr Obes. 2012;7:284-94.

18. Bauer KW, Marcus MD, El Ghormli L, Ogden CL, Foster GD. Cardio-metabolic risk screening among adolescents: understanding the utility of body mass index, waist circumference and waist to height ratio. Pediatr Obes. 2015;10(5):329-37.

19. Associação Brasileira de Empresas de Pesquisa - ABEP. Critério de Classificação Econômica Brasil. São Paulo: Associação Brasileira de Empresas de Pesquisa. 2014.

20. Guedes DP, Lopes CC. Validation of the Brazilian version of the 2007 Youth Risk Behavior Survey. Rev Saude Publica. 2010; 44(5):840-50.

21. Guedes DP, Guedes JERP. Measuring physical activity in Brazilian youth: reproducibility and validity of the PAQ-C and PAQ-A. Rev Bras Med Esporte. 2015;21(6):425-32.

22. Kann L, McManus T, Harris WA, Shanklin SL, Flint KH, Hawkins J et al. Youth Risk Behavior Surveillance - United States, 2015. MMWR. 2016; 65(4).

23. Gómez LF, Lucumí DI, Parra DC, Lobelo F. Niveles de urbanización, uso de televisión y video-juegos en niños colombianos: Posibles implicaciones en salud pública. Rev Salud Pública. 2008;10(4):505-16.

24. Carson V, Janssen I. Neighborhood disorder and screen time among 10-16 year old Canadian youth: a cross-sectional study. Int J Behav Nutr Phys Act. 2012;9:66.
25. Pearson N, Braithwaite ER, Biddle SJ, Van Sluijs EM, Atkin AJ. Associations between sedentary behaviour and physical activity in children and adolescents: a meta-analysis. Obes Rev. 2014;15:666-75.

26. Biddle SJ, Petrolini I, Pearson N. Interventions designed to reduce sedentary behaviours in young people: a review of reviews. Br J Sports Med. 2014;48:182-6.

27. Temple JL, Giacomelli AM, Kent KM, et al. Television watching increases motivated responding for food and energy intake in children. Am J Clin Nutr. 2007;85:355-61.

28. Marsh S, Ni Mhurchu C, Maddison R. The non-advertising effects of screen-based sedentary activities on acute eating behaviours in children, adolescents, and young adults. A systematic review. Appetite. 2013;71:259-73.

29. Dewald JF, Meijer AM, Oort FJ, Kerkhof GA, Bögels SM. The influence of sleep quality, sleep duration and sleepiness on school performance in children and adolescents: a metaanalytic review. Sleep Med Rev. 2010;14:179-89.

30. Dube N, Khan K, Loehr S, Chu Y, Veugelers P. The use of entertainment and communication technologies before sleep could affect sleep and weight status: a population-based study among children. Int J Behav Nutr Phys Act. 2017;14(1):97.

Recebido: 20/08/2017

Aprovado: 29/11/2017

\section{Quote this article as:}

Guedes DP, Desidera RA, Gonçalves HR. Prevalence of excessive screen time and associated correlates in brazilian schoolchildren. Rev Bras Ativ Fis Saude. 2018;23:e0003. DOI: 10.12820/rbafs.23e0003 